\title{
Rethinking Play, Diversity and Belonging in Early Childhood Education
}

\author{
Sonja ARNDT | ORCID : 0000-0003-0778-1850 \\ Dr; Melbourne Graduate School of Education, University of Melbourne, \\ 100 Leicester Street, Carlton 3010, VIC, Australia \\ sonja.arndt@unimelb.edu.au
}

\begin{abstract}
We might say that children's play is the foundation of all learning. Often play is recognized as integral to childhood, but children's abilities to engage in play are complex and these complexities can be easily overlooked. This paper elevates children's play as critical for their learning, particularly in support of their sense of belonging. The paper argues for an openness to the complexities of children's play as a crucial practice of their cultural identity, through a critical conceptualization of some of the nuances and uncertainties of children's subject formation.

Drawing on concerns of cultural difference in early childhood education, Julia Kristeva's foreigner lens and her theory on the subject in process are used to theorise children's play as an ongoing process of belonging. Through the notions of the semiotic, abjection, love and revolt, the notion of the subject in process is elaborated to reconceptualize play as also in-process and ongoing. Rethinking play as a vital process within the sometimes difficult, often unpredictable experiences of becoming part of a centre community is elevated as crucial for a sense of belonging in early childhood education.
\end{abstract}

\section{Keywords}

cultural difference - subject formation - play - belonging - intercultural pedagogies Julia Kristeva 


\section{Introduction}

Children's feeling of belonging is fundamental to their overall wellbeing in early childhood settings. It is also often reflected in their play. This paper presents a critical, philosophical argument for the crucial connections between belonging and play, not only to recognize play, but to reconceptualize it as fundamental to an ongoing process of developing a sense of belonging. Drawing on concerns of cultural difference in early childhood education, Julia Kristeva's foreigner lens and her theory on the subject-in-process are used to theorise and rethink children's play. Through the notions of the semiotic, abjection, love and revolt, the notion of the subject-in-process is elaborated to reconceptualize play as also in-process and ongoing. The paper argues for a shift in thinking, using philosophy as an ethical engagement with thought, to support attitudes towards play in early childhood settings. While the thinking in this paper draws on the Aotearoa New Zealand early childhood context as a foundation, the conceptual ideas are intended to relate to children's play and cultural difference in diverse contexts. The paper begins with highlighting some concerns with attitudes to difference and diversity within the early childhood context (Arndt, 2017), using philosophy as a method for critically reconceptualising children's play (Koro-Ljungberg et al., 2015; Arndt, 2017). Play, like children's subject formations and cultural identity, is highly contingent and context specific. Following this reconceptualization, it may also be a crucial element in children's development of a sense of belonging.

Using Julia Kristeva's poststructural feminist work on subject formation and the foreigner offer the philosophical grounding for this reconceptualization. The paper draws particularly on Kristeva's idea that, as human beings, we are always subjects-in-process and in certain ways 'the foreigner' (Kristeva, 1991). Considering children as subjects who are in the process of becoming in this way elevates the complexities of children's cultural identity, their sense of belonging, as an unresolved process. Adopting this Kristevan lens thus helps to develop an argument for rearticulating children's play in early childhood settings as similarly complex and uncertain, and it raises questions about the importance of moving beyond expectations of an unerring truth on play or specific strategies for play. The next section gives some background to the concerns with cultural difference in early childhood settings, how these are often shaped by teacher attitudes and orientations, and prevailing responses to the cultural diversity present in their settings. The Kristevan examination and reconceptualisation of children's play and belonging follows in the second half of the paper. 
Like many other countries, Aotearoa New Zealand has a highly diverse immigrant population. As one influence, for example, recent changes to refugee quotas and the skills shortage list influence the cultural make up of many communities (Ministry of Social Development, 2016). The impact of policies on early childhood settings has affected increasing attendance by children and teachers from ethnic and linguistic minorities (Arndt, 2018; Mitchell et al., 2015; Loveridge, et al., 2012). While extensive research has been conducted on ways to support children from diverse cultural backgrounds and their families, Cherrington and Shuker (2012) emphasise a gap in teachers' understandings of the nature of belonging. They highlight in particular how this gap relates to teachers' attitudes and orientations towards cultural difference. Within this landscape, teachers' approaches to diversity in their settings can be problematic. When teacher attitudes are grounded in treating differences as the same, for example, or as non-existent, they perpetuate homogenising practices and exacerbate already normalising policy interpretations (Rivalland \& Nuttal, 2010; Cederman, 2008; Arndt et al., 2015). Baldock (2010) notes with concern, that cultural diversity is seen as a 'problem' in early childhood education. In this paper this 'problem' is examined in terms of children's forming cultural identities within their early childhood settings, as a foundation for its call for reconceptualising play as not only emerging through, but as a process of children's ongoing identity formation and sense of belonging.

Teacher attitudes towards difference influence children's belonging in a range of ways. Guo's (2015) work explicates the difficulties that teachers experience in engaging critically with children's cultural differences. Teachers' treatments of children's difference, she observes, rarely draw on critical understandings of culture and how it can play out but arise largely from their own cultural experiences. Further studies show how the complexities and interplay of theory and understandings of children's experiences of belonging, derives to a large extent from what teachers make of their professional identity, within their own political, curricular, social, and relational contexts (Duhn, 2010, Moss, 2006, 2010; Urban, 2014). To position children's play in relation to experiences of belonging thus depends on promoting critical ways of thinking about difference, confronting attitudes and orientations in ways that might not have been previously considered. A key element of the Child and Youth Wellbeing strategy that was recently released in New Zealand (Department of the Prime Minister and Cabinet, 2019), for example, is that shifting attitudes is crucial, for provoking more of an atmosphere that challenges dominant wisdoms within educational settings, and ultimately in society. 
Seminal international research supports critical intercultural pedagogies. An openness to intercultural ways of being, and ongoing attention to social justice and equity concerns are dominant considerations. Taking cultural competence, as Chen (2016) does, as the "ability to work with and relate to people who are not like us", means that ongoing reconceptualisations of intercultural practices is crucial, to avoid perpetuating marginalisations in multicultural settings (Rhedding-Jones, 2000, 2001; Dervin, 2016; Robinson \& Jones Diaz, 2016). For children to experience what it means and feels like to relate to others who are not like themselves, involves children learning through diverse encounters of cultural differences. This, in turn, implicates teachers' orientations towards play to offer such opportunities. Reflecting on the importance of teachers' attitudes, Cherrington and Shuker have argued that enhancing "educators' attitudes and knowledge about diversity are key priority areas if we are to better understand how practitioners can work effectively with children, families, and colleagues from diverse backgrounds" (2012, p. 89). Rethinking play as an ongoing process might involve a reconceptualization of 'attitudes and knowledge', as well as of what 'working effectively with children from diverse backgrounds' entails.

Recognising that children grow up amongst many different cultures and ethnicities, Te Whāriki, the New Zealand early childhood curriculum framework, calls for teachers to be "aware of the different views that the cultures represented in their ECE setting may have" (Ministry of Education [MoE], 2017, p. 19). The curriculum framework suggests that culture itself is a difficult concept. Dervin explains that culture is lived and felt in many ways, that are "neither bounded nor closed" and that "it is not homogeneous" (2016, p. 9). Furthermore, culture can be seen as socially constructed, arising from teachers' and children's individual and collective encounters and experiences, histories and day to day realities. When teachers from minority cultures describe feeling left out, full of "frustration, difficulties, alienation and isolation" (Lee \& Dallman, 2008, p. 40), where their own differences are delegitimised, this influences not only themselves, then, but the experiences and relational and material culture created for children's play and development of a sense of belonging.

Children's play is highly contextualised. Its contextualising influences come from the policy landscape (Tesar \& Arndt, 2017) and from the focus of educational institutions and practices in that landscape (Hood, 2019). Recent 
research conducted in New Zealand schools, Hood states, has, for example, found that children do not "know how to play". Play, however, is fundamental to the socio-cultural framing of Te Whäriki, and is considered as an essential mediator for the relational learning that the curriculum espouses. Play-based experiences, the curriculum suggests, lie at the root of how "children learn to make sense of their immediate and wider worlds through exploration, communication and representation" (MoE, 2017, p. 17), including using play opportunities "and their imaginations to explore their own and others' cultures and identities" (MoE, 2017, p. 17). Such a Te Whāriki-inspired play environment reflects a view of children as competent, confident, and agentic. It infers that they have a strong sense of belonging, are respected, and treated with sensitivity in terms of their cultural background and realities.

For children to engage in such a way makes some important assumptions. For example, if children are to engage in exploration through play, to make sense of their worlds as the curriculum promotes, assumes that they know how to do that, in the context of their early childhood environment. It assumes that they know where and how to access the toys that they want to play with, that they know who they can ask for assistance, and how to do that. It also assumes that they have a sense of when and how they should behave 'appropriately', and how to communicate effectively for their own purposes with those (teachers and other children) around them, of the routines and timelines, and of the unwritten rules that inhere in the early childhood setting. Perhaps, however, we cannot assume such a level of insight or knowledge, or that it would be accessible for all children. Perhaps, we cannot even assume that we are able to know what children know, and how they feel. And perhaps these concerns limit children's play and consequently their sense of belonging in their early childhood setting.

In the simultaneously multicultural and indigenous-non-indigenous cultural confluence of New Zealand, children's play, as with their cultural belonging and difference, arises not in a simple dialectic of themselves in relationship with others. Rather, both are complex, and influenced, for example by practices grounded in Te Whäriki, as well as in the Treaty of Waitangi (Orange, 1989), that is the Treaty signed in 1840 to protect the rights of both Māori and Pākehā (non-Māori), to partnership, protection and participation. Despite many disputes related to the implementation of the Treaty, it nevertheless fundamentally grounds early childhood pedagogies and practices in the consideration of culture as deeply related to an individual's identity, belonging and life. Dervin (2016) continues that culture is multi-layered and encompasses such considerations as ideological differences, biases, habits, opinions and attitudes. In this sense, the non-homogeneous nature of children's culture is, as Kristeva states, reflective of the "non-existence of banality" of all "human 
beings" (1991, p. 3). This 'non-banality' might play out in children feeling that their voices are not heard, and impact on their play, their abilities to engage, and their sense of belonging. Rethinking understandings of children's play in early childhood settings requires a rethinking therefore, of the very reverence of knowledge and certainty as the answer to the 'problem' of children's diversity.

Rethinking play means rethinking teacher attitudes towards diversity. This involves also rethinking the reverence of certainty and knowledge, that exposes how sometimes dominant conceptions posit other knowledges as invalid, a non-knowledge. Such a reverence thus discredits those who are different: the child, the cultural other - as deviating from accepted norms, as invalid. One dominant conception is that managing the 'problem' of diversity is achievable if teachers have sufficient knowledge about those who come from diverse backgrounds. Such knowledge is seen as leading to particular strategies and practices that are considered to be 'correct' or 'useful' in multicultural educational settings (Ho et al., 2004; May \& Sleeter, 2010; Robinson \& Diaz, 2016; Walsh, 2007). Any attempts at homogenising practices can be risky, however, as they commonly fall back on and reinforce dominant worldviews, neglecting the view of culture as a complex, often uncertain and socially constructed concept and experience. Striving for particular or 'useful' knowledge as a foundation for developing children's play and their sense of belonging might ultimately even be dangerous, if it is based on simplistic or superficial, dominant views on what play even is, and what it might mean in any particular culture or local environment. Adding to this unpredictable situation, fully knowing any individual child is difficult, and, following Kristeva's notion of the foreigner, unachievable, as will be further outlined below.

Engaging with children's play through their sense of belonging thus raises two urgent calls. First, it urges an openness towards the uncertainty of teaching and learning across cultural differences. Secondly, it raises the potential for critical philosophical thought to engage with the nuances of children's realities through young children's play and their developing identities. The next section of this paper applies Kristeva's philosophy on the subject-in-process and her notion of the foreigner to provoke a useful framework for rethinking some of the intricacies of children's play in relation to their subject formations and belonging. Using this philosophical framework reveals critical nuances and complexities that support a reconceptualisation of play as not only reflective of but fundamentally important in developing a sense of belonging in young children. 
Julia Kristeva's poststructural, feminist philosophy offers a useful tool for challenging concepts, and for opening conceptual spaces to complexity. Kristeva's work has been used to shift conceptions towards increasingly ethical and critical understandings in linguistic, psychoanalytic and philosophical circles (Lechte, 1990). Noting that it has rarely been applied in education (Söderbäck, 2012), this paper applies her philosophy to rethink and re-articulate children's cultural difference in early childhood education in increasingly nuanced ways. It recognises children as cultural members of an early childhood community, and as players and learners. This examination responds to the concerns and context outlined above in relation to culture, play and belonging. It introduces what is referred to as 'Kristeva's foreigner lens', as a provocation for rethinking attitudes towards children from diverse cultural backgrounds and culminates in a reconceptualization of their play as a critical part of the process of children's forming identities and sense of belonging.

\subsection{Kristeva's Foreigner Lens}

Kristeva's (1991) foreigner lens stresses the difficulty of being able to know the other. She develops the notion of the foreigner from her philosophical, linguistic and psychoanalytical work, to explicate some of the awkwardness, uncertainty, and changeability of conceptions of the self in relation with the self, and with the other. For Kristeva (1991), the concept of being the other, or the foreigner, is fluid and fluctuating. Following her thinking, for children from different cultural backgrounds being the foreigner might involve various forms of being removed from their origins, from their home (or mother-) land, or from other places of safety, or their known or unknown pasts. Being foreign could feel like a "demented whirl" (Kristeva, 1991, p. 6), where a child never exclusively feels they are in one or another place or state. The child-foreigner can be rootless, a 'wanderer', in a physical or metaphorical understanding of the word, hiding behind a range of identities in their attempts to fit in with their new early childhood community, place, or environment.

Kristeva's foreigner lens exposes some of the complexities of being the foreigner, and of the idea that all individuals are implicated by foreignness. Most importantly, she raises the idea that individuals are always foreigners not only to others, but within and to themselves. To understand this idea, she questions whether everybody can not only "live with ... others" but also "live as others" (Kristeva, 1991, p. 2, emphasis in the original), as, Kristeva continues, "strangely ... the foreigner lives within us" (1). In other words, children are always in 
various ways foreigners to themselves, unknown and unknowable. Even as they learn more about themselves, and increasingly develop particular understandings of their identities and belonging, there will always be an element of the unknown. Furthermore, Kristeva (1991) claims that it is only once individuals recognise this foreigner within themselves, that other foreigners, or those who are from different cultural backgrounds or traditions, become less threatening.

The idea that children and teachers embody a variable and constantly evolving foreigner within themselves affects conceptions of children's belonging. It means that what is knowable about them and others can only ever be temporary, as any such knowledge becomes quickly out-dated and superseded (Todd, 2004). Immersed not only in a public and political uncertainty, as outlined in the contextual overview above, but also in their own private 'demented whirl' of nuanced realities, children's revelations about themselves might be risky and incomplete, rather than representative of any total or final truth (Kristeva, 1991; Todd, 2004). This orienting argument crucially affects who is seen as the other in an early childhood setting and unsettles assumptions about children's sense of belonging in that environment. It provokes an attitudinal shift through the recognition that all children and their teachers are foreigners - and hence unknowable - not only to others but also to themselves.

Kristeva's (1991) notion of the foreigner illustrates the uncertainty that teachers might feel when unsettling their ways of knowing about children from diverse cultural backgrounds. Steeped in the notion that "we cannot have first-hand knowledge of another's life" (Todd, 2004, pp. 338-339), it renders teachers' quest for knowing children almost impossible. Similarly, supporting children's play following any 'true' 'knowledgeable' or 'managed' script, driven not only by local but also global benchmarks and expectations (United Nations Human Rights, 1989) becomes untenable - and undesirable. Given the strong rights and social justice emphasis that influences many teacher orientations towards others, and towards knowledge of children who are other, it is crucial that play becomes conceptualised beyond what Rhedding-Jones calls the "glibness of 'multiculturalism"' and the danger of producing "yet another normalisation" (2000, p. 5). Conceptualising all children and teachers as foreigners to others and to themselves counters a blanket reproduction of attitudes or approaches towards difference and of the further marginalization and simplification of young children's diverse and multiple cultural and play-related realities. This concept of the foreigner within is underpinned by Kristeva's philosophical theory on the subject-in-process. 
Kristeva's theory on the subject in process explicates some of the intricacies of children's subject formation. Drawing on her notion that identities are "infinitely in construction, deconstructible, open and evolving" (Kristeva, 2008, p. 2), affirms that children are never completely products only of their own experiences, but always also influenced and affected by their pasts, the present and by their contextual surroundings. Rather than returning to conceptions of the child as 'incomplete', as some kind of adult-in-the-making, who still needs to be formed, shaped and characterised in the 'right' ways, or to fit into society in the way that 'proper' or 'complete' adults do, this leads to the idea that in all respects children's subject formation is always in flux, never static. It creates openings for (re)articulations of the complex constantly shifting realities of being the cultural other in an early childhood setting. Key elements of Kristeva's theory involve processes that energise the subject through ongoing meaning making in what she terms the semiotic; that transform the subject through what she calls 'abjection', or expulsion; and that act in a spirit of love as a constant ethical responsibility to the other. The theory of the subject-in-process further involves the notion of revolt, which is a state of ongoing questioning and inner uncertainty (Stone, 2004). Within this ongoing process of subject formation that is evolving, unstatic and highly contingent, each element offers potentially significant inspiration to shift towards more complex articulations of children's play and sense of belonging. Each element contributes to this complexity. First, there is the constant meaning making, represented in the notion of the semiotic.

\subsection{The Semiotic: A Constant Meaning Making}

A constant meaning making process underlies the ongoing construction of the self. In conceptualising the child-subject as in constant process, this meaning making, which Kristeva (1998) calls the 'semiotic', is dependent on the connectedness of children to their surrounding context. It involves their connectedness not only to the immediate early childhood centre and its community, but also to its structures, that is, to its rules, local societal views, norms and expectations. As it acts within the unconscious, the semiotic represents what children may feel but perhaps be unable to articulate, that is nevertheless meaningful about their experiences of difference and similarities, belonging and alienation, in their play and relationships with people, places and things.

The meaning making of the semiotic recognises the connectedness between the child and her context, which Kristeva refers to as the 'symbolic'. McCance confirms Kristeva's insistence on this relationship, stating that subject 
formation always "requires both the semiotic and symbolic modalities" (1996, p. 147). For children from diverse cultures and backgrounds, this involves recognising the fundamental inner knowledge involved in re-forming their daily routines, habits and rituals, as they come to define their play within their new context. Connected always to their inherited genealogies, histories, stories and life practices, children from diverse cultures may attempt to retain remnants of the culture from their previous context, while immersed at the same time in their new context and early childhood setting (Rhedding-Jones, 2001; Dervin, 2016).

Children's play is affected by the semiotic, as it elevates the heterogeneity of their new context. It elevates the importance of multiple meanings, that is, not only those of their own past and present, but of other children in their setting and the families and communities with whom they play. Their play involves strengthening the diverse knowledges arising in their early childhood context, allowing them to experience these aspects in conscious and unconscious, knowable and unknowable ways, as they encounter and interact with peers, teachers and other families in their early childhood relationships. Closely related to the semiotic is another element in the subject-in-process, that involves letting go, or abjection, as children learn about and adopt new ways of playing and being.

\subsubsection{Abjection}

Children's play depends on how they engage with their present experiences and those in the past. Kristeva's notion of abjection refers to the notion of letting go of aspects of the past. It is a form of expulsion. While for adults this might apply to the expulsion of particular, identifiable, ideas, feelings, or practices, this idea is likely to be much more difficult to conceptualise in relation to children. Following Kristeva's (1998) theory of the subject-in-process, abjection represents expulsions or separations that lead to the subject's becoming 'I'. It performs a critical transformational function, leading to a reformed reemergence of the self, through that which is abjected, or expelled. As Kristeva says, "I expel myself, I spit myself out, I abject myself within the same motion through which "I" claim to establish myself" (1982, p. 3, emphasis in the original). This indicates metaphorically, how children's play responds to their surroundings as they knowingly or unknowingly abject or accept their experiences, ideas or feelings. Alongside the semiotic meaning making relationship described above, children also abject, or transform, their prior selves, as they constantly establish and re-establish themselves.

Abjection offers a useful articulation of children's play experiences. This includes, for example, feelings of non-acceptance, of confusion, of a lack of 
ability to engage freely in play, and of feeling inhibited, marginalised or otherwise left out. Cultural difference can be a source of anxiety, where "loss of identity, loss of status, loss of family networks" (Rivalland \& Nuttal, 2010, p. 28) represents possibilities for transformation through abjection and loss. When teacher attitudes favour "sameness" on the "assumption that sameness brings group coherence and reduces conflict" (Rivalland \& Nuttal, 2010, p. 29), children might more consciously choose to abject, or expel, that which might expose or elevate their differences. Worrying homogenisations of culture, in what Chan (2009) has called multicultural ethnocentrism, that "delegitimis[es] historical and localised variations and specificities" (p. 31), highlight the urgency of an increasing openness towards difference and diverse ways of being. Like Guo (2015), Chan argues for the importance of teachers engaging in more depth with diverse pedagogical and cultural discourses, to break down barriers and increase their own and their early childhood settings' openness to the uncertainty created by diversity. The transformative effect of abjection affects conceptions of play, leading to the possibility where it might be seen as an ongoing transformative process, rather than a singular act or event. Kristeva's conception of love is another element in her theory of the subject-in-process.

\subsubsection{Love}

Love implicates a critical responsibility and attention to the other through responsive relational connectedness. The notion of the subject-in-process is underpinned by an ethics of love, driven by a desire to believe, and to care (Stone, 2004). Channelling love towards both individuals and society encompasses teachers' and children's moral, ethical, and personal commitments, to each other, and to the wider communities in early childhood settings. Love opens up to thoughtful, respectful and deeply moral orientations that can compel more than surface level, uncritical practices and attitudes. Guo (2015) cautions that hiding behind an attitude of care and superficial knowledge is insufficient in multicultural educational settings. What is required, she argues, is a commitment to inclusion, agency, active participation, decision-making and identity formation, with transformation as a central concern.

A relationally connected commitment to love affirms and underpins the moral commitment and attention called to teachers' orientations towards children's differences. A Kristevan lens elevates cultural difference to a far deeper concern than reciprocal respect. Different connotations of respect arise from different historical or local perspectives, and from diverse interpretations and meanings of the verbal and non-verbal languages used to convey respect. Similarly, a 'treating them the same' approach even when intended as a sign of respect, repositions difference as a problem. Rivalland and Nuttal explicate 
teachers' rationalization of their positions towards difference, claiming for example that "children notice it ... the difference ... which can then cause ... friction" (Rivalland \& Nuttal, 2010, p. 29), so teachers saw difference as a "potential cause of conflict, which needs to be avoided, diffused and managed" (p. 29). "Sameness", then, was "equated ... with equal opportunity for all" (Rivalland \& Nuttal, 2010, p. 29), so equality is achieved by "treating our children equal and our parents the same" (Rivalland \& Nuttal, 2010, p. 29). Elevating children's play as a transformative process through which they develop a sense of belonging highlights the troubling effect of subjugating diversity in the name of 'sameness as fairness'.

Love inserts an ideal of openness as an essential ingredient into treatments of cultural diversity. An ethics of love embraces an openness to difference at an unknowable level, that is, it recognises "fundamental difference" (Lechte, 1990, p. 32). A capability to love an other, then, involves appreciating, at a level of deep struggling or working towards, accepting each others' difference. This means that love is fundamental to attempts, efforts and orientations towards 'living with and as' the other, as Kristeva (1991) hopes. "Love means being open to change" (Lechte, 1990, p. 32), and in a Kristevan sense it offers the potential for child subjects to form as "an open system" ((Lechte, 1990, p. 32): that is, open to face the wider world, society, their peers and other members of their early childhood setting. It implies an openness that does not pose difference as a threat, as something that ought to be hidden, downplayed or diminished. Children's diversity then could be seen as a stimulus, an ideal, where love becomes an ethical energising and inviting motive for change and transformation in teachers' attitudes towards children's play.

When we consider young children's subjectivities through Kristeva's theory of the subject-in-process, the above conceptions of semiotic meaning making, abjection and love are centrally concerned with raising levels of awareness, experiencing, and examining the paradoxical state of children's play within their early childhood setting. They involve play that helps to form belonging as subjects-in-process, who are ongoingly "reconciling difference while retaining subjectivity" (McAfee, 2004, p. 117). As subjects-in-process children's ongoing subject and identity formation are revealed as diverse and complex. For Kristeva, recognising the foreigner within and the other foreigner furthermore "establishes a politics" (McAfee, 2004, p. 132). Recognising a political motivation grounds children's play in an ethics not only of love, but also, of encounters, roles and responsibilities, arising through their differences. It is put to work through the final element of the theory of the subject-in-process, Kristeva's conception of revolt. 


\subsubsection{Revolt}

Revolt offers opportunities for developing a more complex recognition and articulation of children's play as a process of developing belonging. Through a Kristevan lens, revolt is a process and a commitment to deep and critical questioning and thought (Kristeva, 2014). In this process of ongoing questioning, Kristeva (1998/2002) points out that revolt is not necessarily some kind of major revolution. Instead, it refers to the "little things, tiny revolts" (Kristeva, 2014, p. 5), which evoke inner change and transformation. In rethinking teachers' orientations to children's difference and their sense of belonging in early childhood settings, Kristeva's notion of revolt therefore adds a permanent state of inner questioning. By opening up thought and attitudes through and ethics of love, revolt counters the risk of children's differences becoming suppressed and hidden. It urges not only a re-thinking, but a re-acting, through its constant questioning.

A commitment to revolt evokes a questioning attitude. It responds to the danger of focusing narrowly on practices of sameness, equality, or supposed "commonalities of all humanity" (Rhedding-Jones, 2000, p. 5), by offering an approach to resist generalising techniques or strategies. In doing so it helps to avoid normalising practices, and counters the expectation that what works in one situation will be appropriate in another (Biesta, 2010). Revolt counters what Kristeva (1991) calls 'leveling'. Rather than enhancing their sense of belonging, unquestioning leveling practices can disconnect children from play and from their early childhood settings. When teachers develop an attitude and practice of revolt they establish a hopeful way to elevate children's play as a transformative process of developing a sense of belonging, by recognizing the complexity, intimacy and intricacy of each child's realities.

Revolt, following Kristeva (2014), involves digging deeply into meanings and conceptions. Its continuing questioning inspires thinking through difficult discourses and realities. It offers the potential to develop increasingly complex engagements with and conceptions of knowing those who are other, to develop insights and thus to enhance children's play and belonging in their early childhood settings. Most crucially, the deep and ongoing questioning of revolt affirms that teachers are unable to know not only those who are other, but also themselves. They are, as Kristeva (1991) claims, always also foreigners within. To reconceptualise children's play as a critical part of the process of their developing sense of belonging within their wider context, means on the one hand to recognize the increasingly globalized and neoliberal positioning of early childhood education as an increasingly important societal indicator and influence (Moss, 2007, 2013). On the other hand it calls into question what Peters and Tesar (2017) have elevated as an erosion of trust and cooperation, and 
resulting ethical and social inequalities. Such inequalities minimize the relational and educational perseverance and long-term commitments, to which $T e$ Whäriki (Ministry of Education, 2017) and recent policy such as what has become called the 'Wellbeing strategy' (Department of the Prime Minister and Cabinet, 2019) aspire.

In such an early childhood environment, children are simultaneously immersed in the macro level politics and the micro-level mundane everydayness of life. It is a complex relational/collective yet individual/neoliberal juxtaposition, as outlined in the contextualisation in the beginning of this paper. As subjects-in-process, the making meaning, ethics of love, and abjection in children's play and their sense of belonging, emerge from this theorisation as deeply entangled, contingent and intricate. Conceptualising subject formation and children's cultural diversity through a Kristevan foreigner lens and through her philosophy of the subject-in-process supports this paper's argument for conceptualising more critical encounters with cultural difference and knowledge. At the same time, Kristeva's notion of the foreigner offers an opportunity for a revolt-ful commitment to a deep and ongoing intimate questioning not only of the other, but of the self. Crucially, this reconceptualization does not offer any solutions or answers to the so-called 'problem' of cultural diversity. Rather, it provokes diverse ways of thinking about and an ongoing questioning of play as crucial in the formation of children's belonging.

Kristeva raises the idea that all individuals are subjects that are always in process, and that they are also always foreigners within. Young children are entangled in diverse confluences of cultural identities and practices within local and global early childhood landscapes. This paper has argued for a reconceptualization of children's play as a crucially transformative and ongoing process that supports children's forming cultural identity and sense of belonging in their early childhood settings. Such a reconceptualization demands a rethinking and re-articulation of teacher attitudes and orientations towards cultural diversity that go beyond the surface, which are open to and allow for the difficult, unpredictable processes of children's belonging and becoming part of an early childhood community.

Kristeva's theory of the subject-in-process and her foreigner lens have offered new ways of articulating some of the raw, nuanced intricacies of cultural diversity. The paper has called for increasingly open attitudes towards both play and diversity in early childhood settings, through a philosophical approach 
to thinking and questioning conceptions of being other. It culminates in an energized, critical and thoughtful practice of questioning and transformation that is both necessary and possible, through Kristeva's notion of revolt. Kristeva's philosophical challenges offer new potential for continually rethinking play to recognise it not only as indicative of, but as a critical process in, children's ongoing development of cultural belonging.

\section{References}

Arndt S. (2017). (Un)Becoming Data through Philosophical Thought Processes of Pasts, Presents and Futures. In M. Koro-Ljungberg, T. Löytönen, \& M. Tesar (Eds.). Disrupting Data in Qualitative Inquiry: Entanglements with the Post-Critical and PostAnthropocentric. (pp. 91-102). Peter Lang. http://doi.org/10.3726/b11070.

Arndt S. (2018). Early Childhood Teacher Cultural Otherness and Belonging. Contemporary Issues in Early Childhood Special Issue: Interrogating belonging in diverse early years settings.19(4), 392-403. https://doi.org/10.1177/1463949118783382.

Arndt S, Gibbons A and Fitzsimons P (2015). Thriving and Surviving, and the Incredible Problem of Constructions of Normality and Difference in Early Childhood Settings. Global Studies of Childhood Special Issue: Regulating Childhoods: Disrupting Discourses of Control, 5(3), 279-290. https://doi.org/10.1177/2043610615597144.

Baldock P. (2010). Understanding Cultural Diversity in the Early Years. Sage.

Biesta G. (2010). Why 'what works' still Won't Work: From evidence-based education to value-based education. Studies in Philosophy and Education, 29(5), 491-503.

Cederman K. (2008). Not Weaving but Drowning? The Child.Com in New Zealand Early Childhood Pedagogies. International Journal of Early Childhood, 4o(2), 119-130.

Chan, A. (2009). Critical Multiculturalism: The challenge of multiculturalism within a New Zealand bicultural context - a Chinese perspective. International Journal of Equity and Innovation in Early Childhood, 7(1), 29-40.

Chen, M. (2016). Migration has Made New Zealand a Great Country - now we have a chance to become a cultural world leader. NZ Herald. http://www.nzherald.co.nz/ nz/news/article.cfm?c_id=1\&objectid $=11575308$.

Cherrington, S., and Shuker, M.J. (2012). Diversity amongst New Zealand early childhood Educators. New Zealand Journal of Teachers' Work, 9(2), 76-94.

Department of the Prime Minister and Cabinet. (2019). Child and Youth Wellbeing Strategy. https://childyouthwellbeing.govt.nz/resources/child-and-youth-wellbeingstrategy.

Dervin F. (2016). Interculturality in Education: A theoretical and methodological toolbox. Palgrave Macmillan. 
Duhn I. (2006). The Making of Global Citizens: Traces of cosmopolitanism in the New Zealand early childhood curriculum, Te Whāriki. Contemporary Issues in Early Childhood, 7(3), 191-202.

Duhn I. (2010). 'The Centre is My Business': Neo-liberal politics, privatisation and discourses of professionalism in New Zealand. Contemporary Issues in Early Childhood, 11(1), 49-6o.

Guo K. (2015). Teacher Knowledge, Child Interest and Parent Expectation: Factors Influencing Multicultural Programs in an Early Childhood Setting. Australasian Journal of Early Childhood, 4o(1), 63-70.

Ho E., Holmes P. and Cooper J. (2004). Review and Evaluation of International Literature on Managing Cultural Diversity in the Classroom. Ministry of Education.

Hood, N. (2019). Playing with Kowledge: towards a broader conceptualisation of play in New Zealand schools. The Education Hub, https://theeducationhub.org.nz/ playing-with-knowledge-towards-a-broader-conceptualisation-of-play-in-newzealand-schools/.

Kelsey J. (2015). The Fire Economy: New Zealand's reckoning. Bridget Williams Books.

Koro-Ljungberg M., Carlson D., Tesar M., and Anderson K. (2015). Methodology Brut: Philosophy, Ecstatic Thinking, and Some Other (unfinished) Things. Qualitative Inquiry, 21(7), 612-619. https://doi.org/10.1177/1077800414555070.

Kristeva J (1982). Powers of Horror: An Essay on Abjection (L. S. Roudiez, Trans.). Columbia University Press.

Kristeva J. (1991). Strangers to Ourselves. Columbia University Press.

Kristeva J. (1998). The Subject in Process. In P. Ffrench \& R.-F. Lack (Eds.), The Tel Quel reader (pp. 133-178). Routledge.

Kristeva J. (2008). “Does European Culture Exist?". Paper presented at the Dagmar and Václav Havel Foundation vize 97 prize, Prague Crossroads. http://www.vize.cz /download/laureat-Julia-Kristeva-en-speech.pdf.

Kristeva J. (2014). New Forms of Revolt. Journal of French and Francophone Philosophy, 12(2), 1-19. http://doi.org/10.5195/jffp.2014.650.

Lechte J. (1990). Julia Kristeva. Routledge.

Lee S. and Dallman M.E. (2008). Engaging in a Reflective Examination about Diversity: Interviews with Three Preservice Teachers. Multicultural Education, Summer, 15(4), $36-44$.

Loveridge J., Rosewarne S., M.J., Shuker M.J., Barker A. and Nager J. (2012). Responding to Diversity: Statements and Practices in Two Early Childhood Education Contexts. European Early Childhood Education Research Journal, 2o(1), 99-113. http://doi.org/ 10.1080/1350293X.2011.634998.

McAfee N. (2004). Julia Kristeva. Routledge.

McCance D. (1996). L'écriture Limite: Kristeva's postmodern feminist ethics. Hypatia, 11(2), 141-160. 
May S. and Sleeter C.E. (2010). Critical Multiculturalism: Theory and praxis. Routledge. Ministry of Education (2017). Te Whāriki: he whāriki mātauranga mō ngā mokopuna o Aotearoa: Early childhood curriculum. New Zealand Government. https://www .education.govt.nz/assets/Documents/Early-Childhood/Te-Whariki-Early-Child hood-Curriculum-ENG-Web.pdf.

Ministry of Social Development (2016). The Changing Face of New Zealand. http:// www.msd.govt.nz/about-msd-and-our-work/work-programmes/initiatives/ connecting-diverse-communities/why-was-this-work-started.html.

Mitchell L. (2013). Markets and Childcare Provision in New Zealand: Towards a fairer alternative. In E Lloyd \& H Penn (Eds.). Childcare Markets: Can they deliver an equitable service? (pp. 97-113). The Policy Press.

Mitchell, L., Bateman A., Ouko A., with Gerrity R., Lees J., Matata K., Xiao W. (2015). Teaching and Learning in Culturally Diverse Early Childhood Settings. Wilf Malcolm Institute of Educational Research (WMIER).

Moss P. (2006). Structures, Understandings and Discourses: Possibilities for reenvisioning the early childhood worker. Contemporary Issues in Early Childhood, 7(1), 30-41. http://doi.org/10.2304/ciec.2006.7.1.30.

Moss P. (2007). Meetings across the Paradigmatic Divide. Educational Philosophy and Theory, 39(3), 229-245. http://doi.org/10.1111/j.1469-5812.2007.00325.x.

Moss P. (2010). We Cannot Continue as We are: The educator in an education for survival. Contemporary Issues in Early Childhood, n1(1), 8-19.

Moss P. (2013). Early childhood and compulsory education: Reconceptualising the relationship. Routledge.

Orange, C. (1989). The Treaty of Waitangi. Bridget Williams Books.

Peters M.A., and Tesar M. (2017). Philosophy and Performance of Neoliberal Ideologies: History, politics and human subjects. In M.A. Peters \& M. Tesar (Eds.), Contesting Governing Ideologies: An epat reader on neoliberalism. Routledge.

Rhedding-Jones J. (2000). Shifting Ethnicities: Foreign whites and others working on antiracist pedagogies in early childhood education. Paper presented at the Australian Association for Research in Education (AARE), Sydney, Australia. www.aare.edu.au.

Rhedding-Jones J. (2001). Shifting Ethnicities: 'Native informants' and other theories from/for early childhood education. Contemporary Issues in Early Childhood, 2(1), $135^{-15}$.

Rivalland C.M.P., and Nuttal J. (2010). Sameness-as-Fairness: Early childhood professionals negotiating multiculturalism in childcare. Early Childhood Folio, 14(1), $28-32$.

Robinson K. and Jones-Diaz C. (2016). Diversity and Difference in Early Childhood Education: Issues for theory and practice (2nd Revised edition Ed.). Open University Press. 
Söderbäck F. (2012). Revolutionary Time: Revolt as temporal return. Signs, 37(2), Special issue on Unfinished revolutions), 301-324.

Stone L. (2004). Julia Kristeva's 'Mystery' of the Subject in Process. In J.D. Marshall (Ed.), Poststructuralism, philosophy, pedagogy (pp. 119-139). Kluwer Academic Publishers.

Tesar, M., \& Arndt, S. (2017). Cross Cultural Complexities of Educational Policies. Policy Futures in Education, 15(6), 665-669. http://doi.org/10.1177/1478210317736181.

Todd S. (2004). Teaching with Ignorance: Questions of Social Justice, Empathy, and Responsible Community. Interchange, 35(3), 337-352.

United Nations Human Rights (1989). Convention on the Rights of the Child. http:// www.ohchr.org/en/professionalinterest/pages/crc.aspx.

Urban M. (2014). Learning from the Margins: Early childhood imaginaries, "normal science", and the case for a radical reconceptualization of research and practice. In M. Bloch, B. Swadener \& G.S. Cannella (Eds.), Reconceptualizing Early Childhood Care and Education, a Reader: Critical questions, new imaginaries \& social activism (pp. 235-252). Peter Lang.

Walsh D.J. (2007). Who are "We"? The Many Dimensions of Culture. Paper presented at the Early Childhood Convention, Rotorua, New Zealand. 